\title{
血液透析患者における家庭血圧測定の意義
}

\author{
栗 山 哲*1 大塚 泰 史*1 飯田 里菜子*1 松 本 啓*1 \\ 菅 緑*2 酒 井 聡一*2 石川 悦久*2 石川 淑 郎*2 \\ 細 谷 龍 男*3 \\ 東京都済生会中央病院腎臓内科*1 石川記念会日比谷石川クリニック*2 \\ 東京慈恵会医科大学腎蔵・高血圧内科*3
}

key words : 早朝高血圧, 家庭血圧, 血液透析, BNP, ANP

〈要旨〉

高血圧の診断·治療において家庭血圧 (home blood pressure：HBP) 測定の重要性が注目されている. 本研究 では慢性腎不全で血液透析 (hemodialysis：HD) 中の患者 106 例において HBP と外来血圧 (office blood pressure : OBP)の両者から血圧管理現況と, HBP の潜在的心疾患や体液量過剰に対する予知能について検討した，1) HBP (朝) においては収縮期高血圧 $81.1 \%$ ，拡張期高血圧 $45.3 \%$ と早朝高血圧が高頻度にみられた。また, HBP(朝) を用いた収縮期血圧管理区分は，管理良好群 $9.4 \%$ ，管理不良群 $65.1 \%$ ，仮面高血圧群 $16 \%$ ，白衣高血圧群 $9.4 \%$ と管理不良例が高頻度にみられた。 HBP(夜)においても収縮期高血圧 $68.9 \%$ ，拡張期高血圧 $34.9 \%$ と高血圧が多 数みられた，また，HBP(夜) を用いた収縮期血圧管理区分は，管理良好群 $12.3 \%$ ，管理不良群 $55.7 \%$, 仮面高血

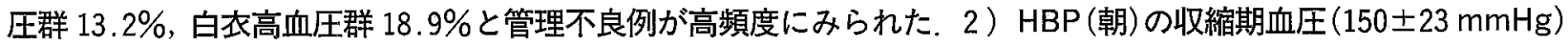
は HBP (夜) ( $145 \pm 20 \mathrm{mmHg}$ ）に比べて有意に高値であるが $(p=0.0297$ by Scheffe's method), OBP の収縮期血 圧 $(150 \pm 20 \mathrm{mmHg})$ とは同等であった。一方, $\mathrm{HBP}$ (朝), $\mathrm{HBP}$ (夜), $\mathrm{OBP}$ の拡張期血圧は三者間に差異はみられ なかった，3）BNP と収縮期血圧の正相関は HBP(朝) $(r=0.249, p=0.0098)$ と HBP(夜) $(r=0.266, p=0.0057)$ の両者でみられた。一方, BNP はOBP の収縮期血圧とは関連性がなかった。 また, BNPと HBP(朝), HBP(夜), OBP の拡張期血圧との間にはいずれも関連性がみられなかった。 4$)$ ANP は, HBP (朝) の収縮期血圧 $(r=0.381$, $\mathrm{p}=0.0112)$ と拡張期血圧 $(r=0.322, p=0.0346)$ いずれとも正相関した．また，透析後の OBP は収縮期血圧 $(r=$ $0.521, p=0.0003)$ と拡張期血圧 $(r=0.453, p=0.002)$ ともにANP と良好な相関関係を認めた。一方, ANPは $\mathrm{HD}$ 前の OBP と HBP(夜)両者の収縮期血圧, 拡張期血圧のいずれとも関連性がみられなかった，以上，HD 患者は OBP, HBP 両者において高頻度に高血圧がみられることから依然として心血管疾患など高血圧性合併症の大きなリ スクを有していると思われた. また, HBP はBNPやANP と関連づけることにより潜在的心疾患や体液過剩の良好 な予知因子となり，高血圧の治療ターゲットとして有用である可能性が示唆された.

\section{Clinical usefulness of home blood pressure measurement in patients on chronic hemodialysis}

Satoru Kuriyama*1, Yasushi Otsuka*1, Rinako lida*1, Kei Matsumoto*1, Midori Suga*2, Soichi Sakai*2, Yoshihisa Ishikawa*2, Toshiro Ishikawa*2, Tatsuo Hosoya*3

Division of Nephrology, Saiseikai Central Hospital ${ }^{* 1}$; Ishikawa Memorial, Hibiya Ishikawa Clinic ${ }^{* 2}$; Department of Kidney \& Hypertension, Jikei University School of Medicine*3

Blood pressure (BP) measured at home (HBP) has been recognized as a useful predictor of organ damage and viewed as an important therapeutic target in patients with hypertension. This study aimed to elucidate whether this tenet holds true for patients on long-term hemodialysis (HD). Enrolled in the study were 106 patients with chronic renal failure receiving standardized HD. They were all directed to record self-measured HBP in the morning and at bedtime to evaluate the adequacy of BP control. In addition, cardiovascular

栗山 哲 東京都済生会中央病院腎臓内科 $\bar{~} 108-0073$ 東京都港区三田 1-4-17

Satoru Kuriyama Tel : 03-3451-8211 Fax : 03-3451-1177

〔受付：平成 18 年 3 月 23 日, 受理 : 平成 18 年 7 月 21 日〕 
complications were estimated by measuring the plasma concentration of BNP and ANP whose clinical implications were analyzed in conjunction with BP. The results were as follows ; 1) HBP in the morning shows the predominance of morning hypertension ( $81.1 \%$ when determined in systolic HBP and $45.3 \%$ in diastolic HBP). The overall status of BP control assessed as a classification based upon the relationship between HBP in the morning and office/clinic BP (OBP) shows that patients with well-controlled systolic HBP in the morning comprised $9.4 \%$, those with poorly-controlled, $65.1 \%$, masked hypertension, $16 \%$ and white-coat hypertension, $9.4 \%$. Additionally, HBP at bedtime also shows the predominance of hypertension $(68.9 \%$ when determined by systolic HBP and $34.9 \%$ by diastolic HBP). The status of BP control shows that patients with well-controlled systolic HBP at bedtime comprised $12.3 \%$, those with poorly-controlled, $55.7 \%$, masked hypertension, $13.2 \%$ and white-coat hypertension $18.9 \% .2)$ Systolic HBP in the morning ( $150 \pm 23 \mathrm{mmHg}$ ) was significantly higher than that at bedtime $(145 \pm 20 \mathrm{mmHg}, p=0.0297$ by Scheffe's method), and was comparable to systolic OBP $(150 \pm 20 \mathrm{mmHg})$. In contrast, diastolic HBP in the morning, diastolic HBP at bedtime and diastolic OBP were all comparable. 3 ) There was a significant correlation between logarithmically converted BNP (In (BNP) expressed as BNP) and systolic HBP in the morning $(r=0.249, p=0.0098)$, and systolic HBP at bedtime $(r=$ $0.266, p=0.0057)$. However, there was no apparent relationship between BNP and systolic OBP. 4 ) There was a significant correlation between logarithmically converted ANP (In (ANP) expressed as ANP) and HBP (both systolic $(r=0.381, p=0.0112)$ and diastolic $(r=0.322, p=0.0346))$ in the morning. There was also a significant correlation between $\ln ($ ANP $)$ and either systolic $(r=0.521, p=0.0003))$ or diastolic OBP $(r=0.453, p=0.002)$ obtained at the end of HD. However, there was no such relationship when evaluated using either HBP at bedtime or OBP. This study indicates that despite ongoing conventional antihypertensive therapy and vigorous efforts to appropriately correct fluid status with standardized HD, the majority of patients on HD have hypertension, suggesting that patients with chronic renal failure are still at higher risk for cardiovascular diseases. Moreover, left ventricular dysfunction accessed by an increase in BNP and excessive volume status accessed by an increase in ANP were predicted by HBP, but not by OBP. To ameliorate hypertension, more appropriate pharmacological interventions and intensive fluid volume management in association with HBP must be further considered for these patients.

\section{緒 言}

近年, 高血圧の臨床研究において家庭血圧（home blood pressure : HBP) の重要性が注目されている. HBP は, 白衣高血圧の発見や降圧薬の薬効評価など において有用であることに加光, 外来血圧 (office blood pressure：OBP）と対比することで仮面高血圧 や管理不良例などの血圧管理状況も明らかにし得 る ${ }^{1 \sim 4)}$. HBPにより検出される早朝高血圧は, 心筋梗 塞，脳卒中，突然死と関連することから脳・心・腎な どの臟器障害の指標となり患者生命予後を推定し得る と考光られている ${ }^{5 \sim 12)}$. 一方, OBP と HBP の両者を 用いて現行の降圧療法の適否を検討した大規模研究か らは, 降圧目標値を達成する患者数が極めて少なく不 十分との評価がなされているい文。

一般に慢性腎疾患に伴う高血圧は病期の進展と共に 重症化し難治性となる ${ }^{13}$. 特に進行性腎障害から末期 腎不全を経て血液透析療法 (hemodialysis：HD) にま で至る患者では高血圧の合併頻度は極めて高く, その 結果として脳・心・腎障害の合併症も高頻度となる。 HBP に注目した糖尿病性腎症患者の研究においては
網膜症, 微小血管症, 大血管症, 腎症などの合併症が 早朝血圧の重症度に応じて発症頻度が増加することが 示されている ${ }^{14)}$. 高血圧性合併症の進展予防には適切 な降圧療法が奏功することに異論はない ${ }^{15,16)}$. しかし， 適切な治療に先立ってまず適切に高血圧の診断をする ことが肝要である。その観点から従来の OBPにのみ 依存した診断・治療は再考の余地がある. 正確な高血 圧の診断には OBP のみに低存せず HBP を利用し血 圧管理区分を明らかにすることが重要と思われる，現 在までの HD 患者における血圧管理の評価は主に OBP によるもので, HBP に注目した成績は極めて少

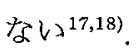

以上のような背景から, 本研究では HD 患者におい て OBP と HBP の両者から血圧管理現況を明らかに することを試み，現行の降圧療法あるいは体液量管理 の適否を検討した，さらに，BNP とANPを surrogate marker として潜在的心疾患あるいは体液量過剩 との関連性についても検討した。

\section{I．対象と方法}

対象患者: 平成 17 年 12 月の時点で東京都済生会中 
央病院と日比谷石川クリニックに外来通院中の慢性腎 不全で維持 HD 中の患者 106 名である. 患者の臨床的 背景は, 平均年齢 $60.9 \pm 12.5$ 歳, 男性 54 例で女性 52 例, 糖尿病性腎症例 36 例 (34\%), 平均透析期間 $42 \pm$ 44 加月, BMI $20.9 \pm 3.2$, 中二日空きの週始めの平均 体重増加率は $4.9 \pm 1.9 \%$ であった。 な拉，心疾患に関 してはNYHA 分類II以上の䫓性心不全症例は除外し た。

HD 処方：対象患者は全例に括いて週三回，一回 4 時間ないし 4 時間 30 分の標準的処方による透析療法 を受けていた。血液流量は $200 \sim 300 \mathrm{~mL} / \mathrm{min}$, 透析液 流量は $500 \mathrm{~mL} / \mathrm{min}$, 透析膜は FB-210U, PS-1.9N な ぞを個々の患者で適宜用いた，透析液の組成は， $\mathrm{Na}$ 140, K 2.5, Ca 3.0, $\mathrm{Mg} 1.5, \mathrm{Cl} 107, \mathrm{HCO}_{3} 27.5$, acetate $7.5(\mathrm{mEq} / \mathrm{L})$, ブドウ糖 $150 \mathrm{mg} / \mathrm{dL}$, 浸透圧 $282 \mathrm{mOsm} / \mathrm{L}$ であった。

家庭血圧測定法 : 家庭での血圧測定は全例で上腕測 定用のオシロメトリック法あるいはコルコトフ法によ る血圧計を用い，測定値は患者個人で記録票に記入し 来院時に透析室スタッフが集計した，HBP 值の決定 は一回測定を原則としたが，患者によって複数回測定 した場合には原則としてそれらの平均値をもって HBP とした。HBP 測定方法は, 日本高血圧学会の家 庭血圧測定条件設定の指針に準じた ${ }^{199}$.すなわち, 起床 後 30 分以内で, 座位にて排尿後, 内服前の条件下に血 圧を測定し朝の家庭血圧值 (home blood pressure： HBP (朝))とした。また，就蔓前に上記と同条件で測 定し夜の家庭血圧值 (HBP (夜)) とした。これに対し て HBP 測定前後で直近の外来受診時, 座位で 30 分間 安静後の HD 開始時に同側上腕で医師あるいは看護 師が測定した血圧值を外来血王 (office blood pressure：OBP) とした。なお，OBP は週初めの透析開始 時の値を, HBP 值は OBP に直近の非透析日のデータ を採用した、例元ば，月・水・金の透析患者であれば， OBP は月曜日の透析開始前, HBP はその直近である 火曜日の朝 $(\mathrm{HBP}($ 朝 $))$ と就漫前の值 $(\mathrm{HBP}($ 夜 $)$ )を 採用した。

血圧管理状況の区分と降圧療法：OBP と HBP の 収縮期血圧, 拡張期血圧との関連から, 雨者が正常血 压を管理良好群, $\mathrm{OBP}$ が高血圧で HBP も高血圧の患 者群を管理不良群, OBP が正常血圧で HBP が高血圧 の患者群を仮面高血圧群(逆白衣高血圧), $\mathrm{OBP}$ が高血 圧で HBP が正常血圧の患者群を白衣高血圧群, 両者 が正常血圧の患者群を管理良好群と呼称した（図 1 か ら図 4). 現時点でHBPにおける高血圧の定義に一定

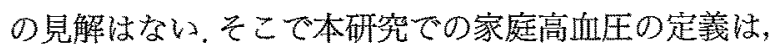

日本高血圧学会の家庭血圧ガイドラインでの高血圧が 135/85 mmHg であることから ${ }^{19}$, 任意の HBP 測定時 に 135/85 mmHg 以上をもって高血圧とした。一方, OBP に肪ける高血圧も同様に日本高血圧学会のガイ ドラインに則り 140/90 mmHg 以上をもって定義し た。な扔，全例 106 例のうち降圧療法を受けている患 者は 82 例 (77.4\%) であり，その内訳はアンジオテン シンII受容体拮抗薬 65 例, アンジオテンシン変換酳素 阻害薬 8 例, $\mathrm{Ca}$ 拮抗薬 74 例, $\alpha_{1}$ 遮断薬 25 例, $\beta$ 遮断 薬 36 例, 交感神経遮断薬 10 例, 利尿薬 32 例であった。 また，二凨以上の降圧薬併用療法を受けている患者は 75 例 $(70.7 \%)$ であり, 併用療法を受けている患者が 多数晋った。

血中 BNP，ANP 濃度測定：ヒト脳性ナトリウム利 尿ペプチド（BNP）とヒ卜心房性ナトリウム利录ペプ チド (ANP) は，透析終了時 HD 患者がドライウェイ トに達したかあるいはドライウェイトの近傍と思われ る条件下（週初めの透析日の終了時）で採血した，血 中 BNP 濃度は CLEIA 法（正常値 $18.4 \mathrm{pg} / \mathrm{mL}$ 以 下), 血中 ANP 濃度 (正常値 $40 \mathrm{pg} / \mathrm{dL}$ 以下) は RIA 固相法によって測定した。週初めの HDでは透析終了 時に患者によってほ必ずしもドライウェイトに達しな い場合もあるが，このような場合にはその条件下での 測定值を採用した。まま, 血中 ANP と血圧の相関解析 は HBP, OBP に加完透析後の OBP の三者に抬いて 検討した。

統計解析：OBP, HBP (朝), HBP (夜) 三群間の 血圧平均値の等分散検定は, Bartlett 検定により行い, 等分散であった場合の検定は one-factor repeated measures ANOVA（Scheffe 法）を用いた。 OBP と HBP 二群間の回帰直線の相関関係は, Pearson の分 析を行い, p 値は FisherのZ変換にて求めた。 また, 二群間の比較には paired, unpaired Student t-test 適宜用いた. BNP と ANP の相関解析において, BNP 実数と対数变換した BNP $(\ln (\mathrm{BNP})$, 以下 $\mathrm{BNP}$ と表 現）あるいはANP実数と対数変換したANP（ln (ANP)，以下ANP と表現)の両者で行ったが, 統計 解析はそれぞれ後者を用いた、BNPやANPなどの医 療生化学検査值は, 対数変換によって正規分布に近づ き,よりパラメトリックな解析に適していることが知 られている。 な极, 得られた成績はすべて平均値士標 準偏差にて表し, 危険率 $5 \%$ 以下をもって統計学的有 意差とした。 
表 $1 \mathrm{OBP}, \mathrm{HBP}($ 朝), $\mathrm{HBP}($ 夜)の比較

\begin{tabular}{crrr}
\hline 血圧 & \multicolumn{1}{c}{ OBP } & \multicolumn{1}{c}{$\mathrm{HBP}($ 朝) } & \multicolumn{1}{c}{$\mathrm{HBP}$ (夜) } \\
\hline 収縮期 & $150.4 \pm 20.1$ & $150.0 \pm 23.3$ & $144.9 \pm 20.0^{*}$ \\
拡張期 & $81.3 \pm 14.5$ & $82.7 \pm 14.2$ & $79.4 \pm 15.5$ \\
\hline
\end{tabular}

OBP : office blood pressure

HBP : home blood pressure

収縮期は one-factor repeated ANOVA で $\mathrm{p}=0.0129$

拡張期は one-factor repeated ANOVA で $\mathrm{p}=0.0707$

${ }^{*} p=0.0297$ vs. OBP, $p=0.0486$ vs. HBP(朝) (Scheffe 検定)

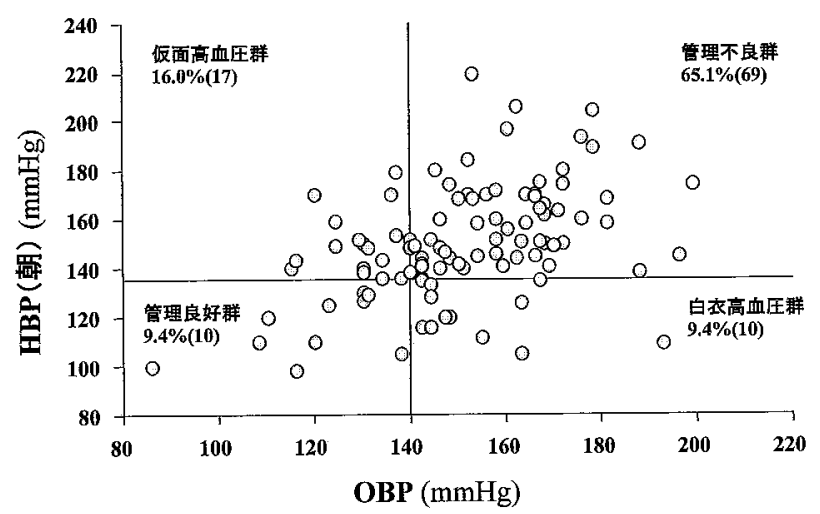

図 1 収縮期血圧からみた管理区分 (OBP vs. $\operatorname{HBP}($ 朝) )

OBP : office blood pressure

HBP : home blood pressure

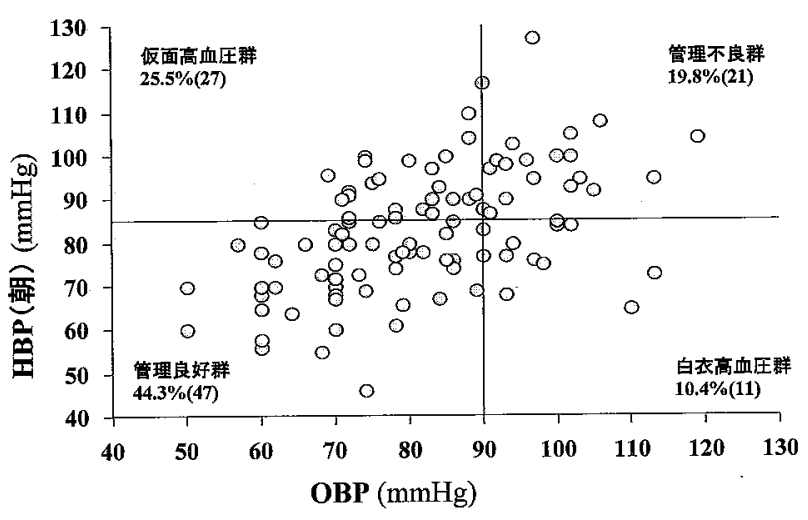

図 2 拡張期血圧からみた管理区分 (OBP vs. $\mathrm{HBP}$ (朝))

OBP : office blood pressure

HBP : home blood pressure

\section{II. 結 果}

表 1 に HD 患者の OBP と HBP の収縮期血圧と拡 張期血圧の比較を示した、収縮期血圧で評価した場合， OBP，HBP(朝)，HBP(夜)の三群間には等分散検定 にて有意差が存在した $(\mathrm{p}=0.0129)$. そのため各々二 群間の有意差を検定した結果，OBP は $\mathrm{HBP}$ (夜)より $(\mathrm{p}=0.0297), \mathrm{HBP}($ 朝 $)$ は $\mathrm{HBP}($ 夜 $)$ より（p=

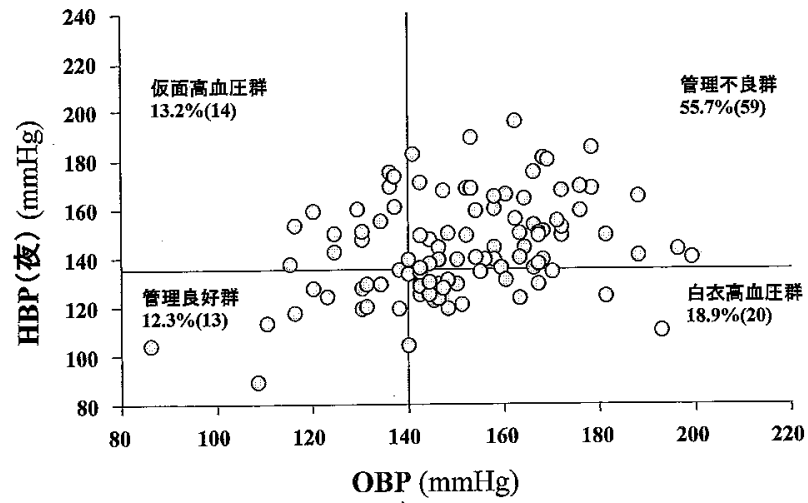

図 3 収縮期血圧からみた管理区分 (OBP vs. $\operatorname{HBP}($ 夜) )

OBP : office blood pressure

HBP : home blood pressure

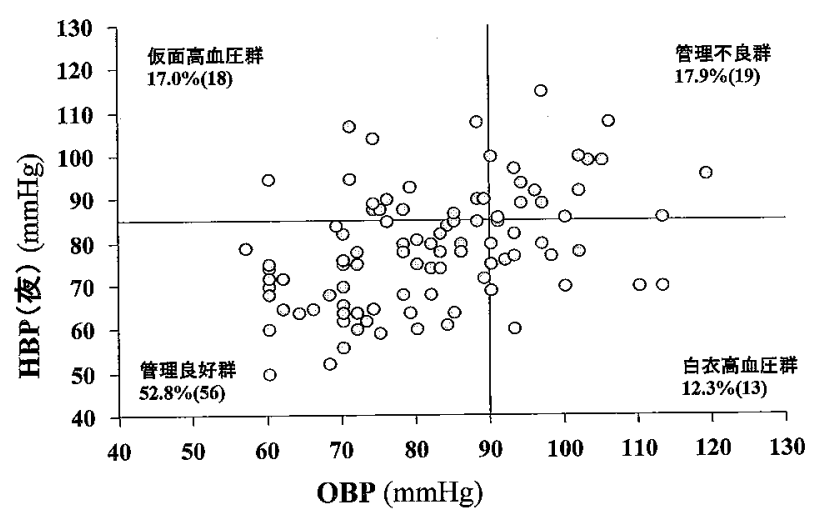

図 4 拡張期血圧からみた管理区分（OBP vs. $\operatorname{HBP}($ 夜))

OBP : office blood pressure

HBP : home blood pressure

0.0486), 統計学的に有意に高值であった。一方, OBP と $\mathrm{HBP}$ (朝) の収縮期血圧レベルは同等であった。こ れに対して拡張期血圧で評価した場合，OBP，HBP (朝), $\mathrm{HBP}$ (夜)の三群間には等分散検定にて有意差が 存在せず $(p=0.0707)$ ，三者は同等な值であった。

図 $1 k \mathrm{OBP}$ と $\mathrm{HBP}$ (朝) の収縮期血圧からみた血 圧管理区分を示した。 その結果, 管理不良群は $65.1 \%$, 仮面高血圧群 $16.0 \%$ ，白衣高血圧群 $9.4 \%$ ，管理良好 群はわずか $9.4 \%$ あった。 また，収縮期血圧 135 $\mathrm{mmHg}$ 以上の早朝高血圧の頻度は $81.1 \%$ (86/106 例)，収縮期血圧 $140 \mathrm{mmHg}$ 以上の外来高血圧は 74.5\%（79/106）であった。

図 2 に, OBP と $\mathrm{HBP}$ (朝)の拡張期血圧からみた血 圧管理区分を示した，血圧管理区分は，管理不良群 $19.8 \%$, 仮面高血圧群 $25.5 \%$ ，白衣高血圧群 10.4\%で あり，管理良好群 $44.3 \%$ あった。また，拡張期血圧 $85 \mathrm{mmHg}$ 以上の早朝高血圧の頻度は, $45.3 \%$ (48/106 例), 拡張期血圧 $90 \mathrm{mmHg}$ 以上の外来高血圧は 

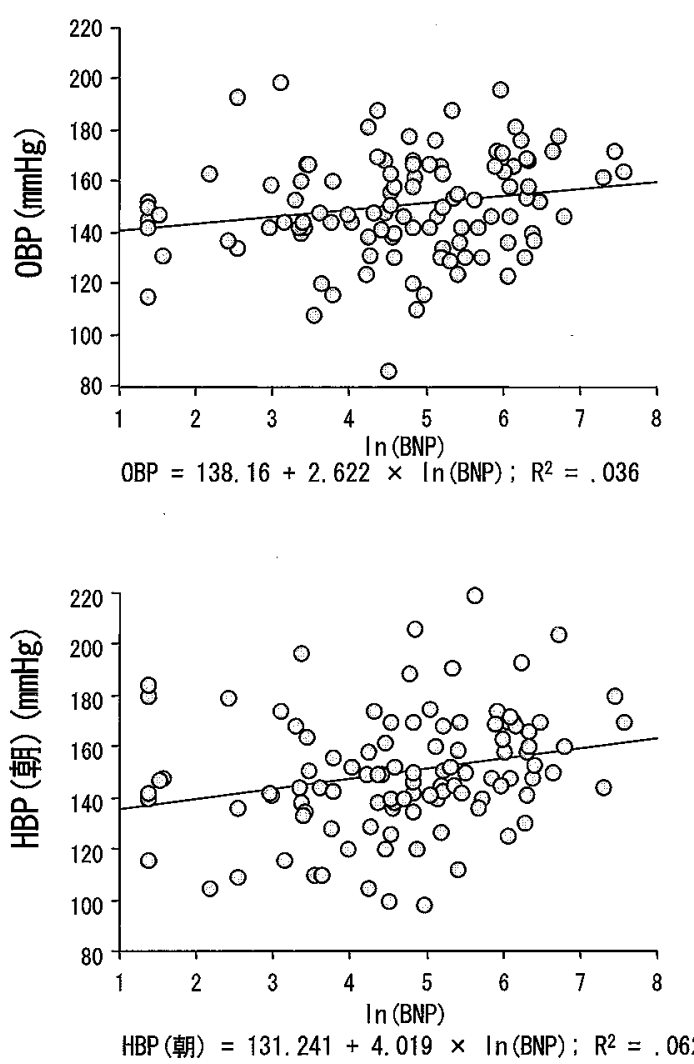

図 $5 \mathrm{BNP}$ と $\mathrm{OBP}, \mathrm{HBP}$ (朝)， $\mathrm{HBP}$ (夜)の相関（収縮期血圧） OBP : office blood pressure, HBP : home blood pressure $\ln (\mathrm{BNP}):$ logarithmically converted BNP
$30.2 \%(32 / 106)$ であった.

図 3 は OBP と HBP(夜) の収縮期血圧からみた血 圧管理区分を示した。その結果，管理不良群 55.7\%， 仮面高血圧群 $13.2 \%$, 白衣高血圧群 $18.9 \%$, 管理良好 群 $12.3 \%$ あっむた．また，収縮期血圧 $135 \mathrm{mmHg}$ 以上 の家庭高血圧の頻度は，68.9\%(73/106 例)，収縮期血 圧 $140 \mathrm{mmHg}$ 以上の外来高血圧は $74.6 \%(79 / 106)$ で あった。

図 4 は $\mathrm{OBP}$ と $\mathrm{HBP}$ (夜) の拡張期血圧分布からみ た血圧管理区分を示した，血圧管理区分は，管理不良 群 $17.9 \%$ ，仮面高血圧群 $17.0 \%$, 白衣高血圧群 $12.3 \%$ ，管理良好群 $52.8 \%$ であった。また，拡㲀期血 圧 $85 \mathrm{mmHg}$ 以上の家庭高血圧の頻度は，34.9\% (37/ 106 例)，拡張期血圧 $90 \mathrm{mmHg}$ 以上の外来高血圧は $30.2 \%$ (32/106) であった.

図 5 は BNP と収縮期血圧でみた OBP， HBP(朝), $\mathrm{HBP}$ (夜) の関連性を示した. BNP は $\mathrm{HBP}($ 朝) と HBP (夜) で有意の正相関が認められるが（それぞれ $\mathrm{r}=0.249, \mathrm{p}=0.0098, \mathrm{r}=0.266, \mathrm{p}=0.0057)$, BNPと OBP の間でこの関連性は認められなかった。 また，血 圧管理区分と BNP の関連の解析では，血圧管理区分 の ANP，BNP のレベルを検討した。その結果, BNP

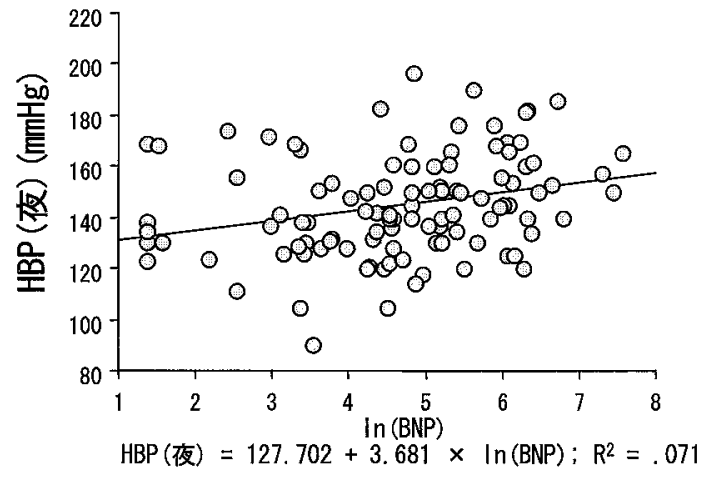

\begin{tabular}{|c|c|c|}
\hline & 相関係数 & $\mathrm{p}$ 值 \\
\hline $\ln (\mathrm{BNP})$ vs. OBP & 0.189 & $\mathrm{p}=0.0524$ \\
\hline $\ln (\mathrm{BNP})$ vs. $\mathrm{HBP}$ (朝) & 0.249 & $p=0.0098$ \\
\hline $\ln (\mathrm{BNP})$ vs. $\mathrm{HBP}$ (夜) & 0.266 & $\mathrm{p}=0.0057$ \\
\hline
\end{tabular}

Fisherのrの $\mathrm{z}$ 変換
は one factor ANOVA で F 值 3.278, $\mathrm{p}=0.0241$ を もって仮面高血圧群 $(167 \pm 162 \mathrm{pg} / \mathrm{mL})$, 管理不良群 $(290 \pm 375 \mathrm{pg} / \mathrm{mL})$, 白衣高血压群 $(57 \pm 65 \mathrm{pg} / \mathrm{mL})$, 管理良好群 $(170 \pm 171 \mathrm{pg} / \mathrm{mL})$ の四群間に有意差があ り,さらに Scheffe の群間比較検定では管理不良群と 白衣高血圧群の二者間で有意差が得られた（ $\mathrm{p}=$ $0.0328)$

図 6 は $\mathrm{BNP}$ と拡張期血圧でみた $\mathrm{OBP}, \mathrm{HBP}$ (朝), $\mathrm{HBP}$ (夜)の関連性を示した. BNP はこれらのいずれ の血圧値との間にも相関関係が認められなかった。

表 2 は血圧值とANPの相関関係を示した. ANP は HBP (朝) の収縮期血圧, HBP (朝) の拡張期血圧 との間にそれぞれ有意の正相関が認められた（それぞ れ $\mathrm{r}=0.381, \mathrm{p}=0.0112$ と $=0.322, \mathrm{p}=0.0346)$.ま た，透析後の収縮期血圧 (OBP (収縮期) - post) と拡張 期血圧 $(\mathrm{OBP}$ (拡張期) - post) は両者ともに ANP と極 めて良好な相関関係を認めた(それぞれ $\mathrm{r}=0.521, \mathrm{p}=$ 0.0003 と $\mathrm{r}=0.453, \mathrm{p}=0.002)$.一方, ANP は OBP, $\mathrm{HBP}$ (夜)の収縮期血圧と拡張期血圧のいずれとの間 にも関連性は認められなかった。なお，血圧管理区分 と ANPの関連の解析において one factor ANOVA で，仮面高血圧群，管理不良群，白衣高血圧群，管理 


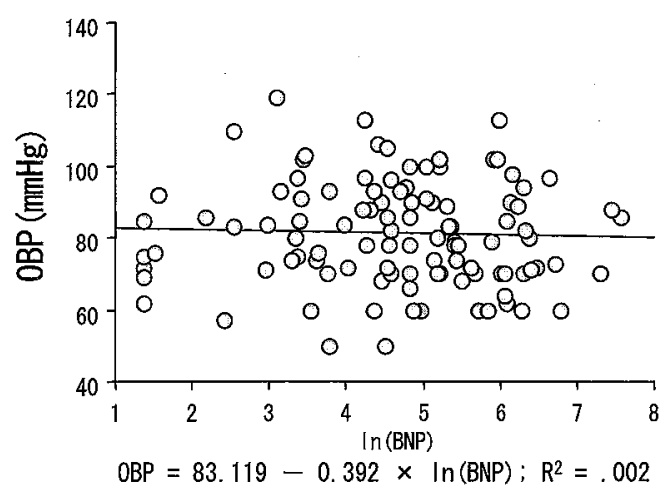

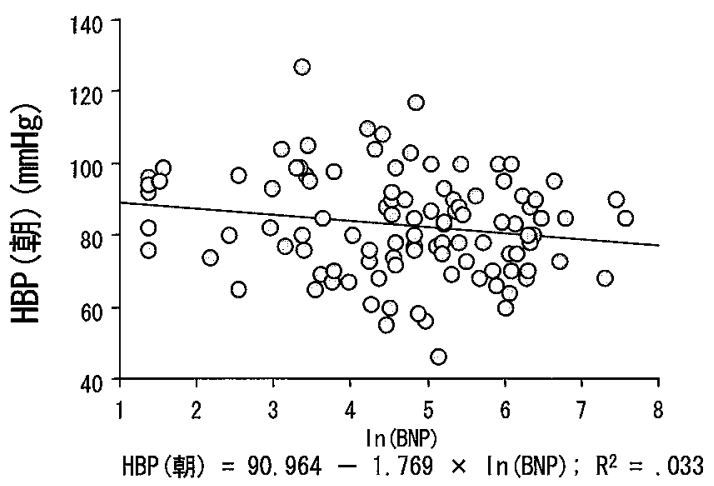

図 $6 \mathrm{BNP}$ と OBP, $\mathrm{HBP}($ 朝 $), \mathrm{HBP}$ (夜)の相関（拡張期血圧） OBP : office blood pressure, HBP : home blood pressure $\ln (\mathrm{BNP})$ : logarithmically converted BNP

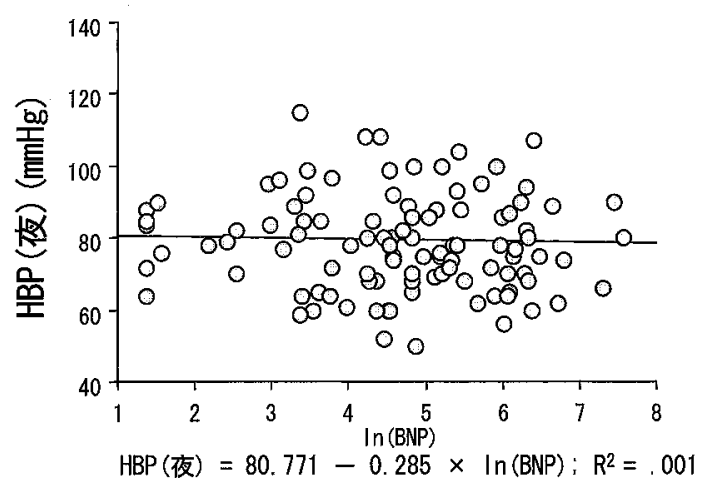

\begin{tabular}{llcc}
\hline & 相関係数 & $\mathrm{p}$ 值 \\
\hline $\ln (\mathrm{BNP})$ & vs. $\mathrm{OBP}$ & -0.039 & $\mathrm{p}=0.6925$ \\
$\ln (\mathrm{BNP})$ & vs. $\mathrm{HBP}($ 朝 $)$ & -0.180 & $\mathrm{p}=0.0643$ \\
$\ln (\mathrm{BNP})$ & vs. $\mathrm{HBP}($ 夜 $)$ & -0.027 & $\mathrm{p}=0.7871$ \\
\hline & Fisher の $\mathrm{r}$ 変換
\end{tabular}

ないこと，(3) ANP も BNP 同様に HBP (朝のみ) と 正相関するが OBP とは関連がないこと，である。

HD 患者の血圧管理状況に関しては, 従来の OBP を用いた研究に扝いても高血圧の合併頻度が極めて高 いことが知られている17,18). 本邦の統計においても $\mathrm{HD}$ 前収縮期 OBP で評価した場合に約 50\%程度に高 血圧がみられる22. 最近, 家庭における HBP 測定が推 奨され，保存期腎不全患者や腹膜透析患者において HBP を測定し血圧管理状況が不十分であるとの成績 が散見される ${ }^{23,24)}$. 一方, HD 患者に扔いて HBP を導 入して血圧管理状沉を報告した成績は未だ極めて少な い. 今回の成績から HD 患者においても外来高血圧と 同様に，家庭高血圧患者が極めて多数である事実が確 認された。HBP (朝) の収縮期高血圧の頻度 (81.1\%) は，OBP の収縮期高血圧のそれ（74.5\%）とほほ同等 で高率であった（図 1)。一方，HBP (朝) の拡張期高 血圧の頻度（45.3\%）は OBP の拡張期高血圧のそれ (30.2\%) と同様に比較的少なかった（図 2). 同様の現 象は $\mathrm{HBP}$ (夜) の収縮期高血圧の頻度（68.9\%）は OBP の収縮期高血圧 (74.6\%) とほほ同等に高いが(図 3), $\mathrm{HBP}$ (朝) の拡張期高血圧の頻度 (34.8\%) は OBP の拡張期高血圧のそれ (30.2\%) と同様に比較的低い 
ことからも確認される (図 4)。このことから HD 患者 の高血圧は主に収縮期高血圧であるといえる，収縮期 高血圧は高齢者や合併症をもつ糖尿病患者など動脈硬 化が高度に進展した患者にみられる大動脈の弾性低下 が主因の高血圧である。一般に HD 患者の高血圧は収 縮期血圧主体で心肥大などの心血管リスクや生命予後 に関連するとの報告が大半であるが，一方で拡張期血 圧と粗死亡率の関連性を観察した研究もあり，どちら が臨床的に重要かは未だ結論はない要，今後は HBP 測定を普及させることで HD 患者の収縮期高血圧と 拡張期高血圧の両面からの解析が必要となろう.

$\mathrm{OBP}$ と $\mathrm{HBP}$ (朝) が収縮期血圧も拡張期血圧にお いても同等な值であった (表 1$). \mathrm{HBP}$ (朝)が $\mathrm{HD}$ 開始 時の OBP と近似するとの本知見は新しい. HD 患者 の血圧は容量依存性に変動し, 週初めの $\mathrm{HD}$ 開始時の $\mathrm{OBP}$ は水・ $\mathrm{Na}$ 貯留で体液量過剩状態が最大になっ ている時間帯である. HBP(朝)が OBP と近似する事 実から, HBP (朝) が HD 患者の体液量過剰状態を比較 的鋭敏に反映したパラメーターであるともい光る。 Kario ${ }^{25}$ は高血圧患者の臨床には早朝の血圧測定值を 新たな治療ターダットにすべきことを強調している が, HD 患者における血圧管理においても HBP(朝)測 定を普及させ管理状況を詳細に把握することが重要と 思われた。

一般に慢性腎不全患者に扮いても，ANPは体液量 過剩の，BNP は体液量過剩の少ない条件下で心肥大 や心不全の surrogate markerとして認識されてい る ${ }^{20,21)}$ ，一方，現在までの HD 患者における BNP と ANP の臨床的意義は OBP との関連で議論され，その 関連性は否定的であった ${ }^{26)}$. 著者らの BNP と ANP をHBP と関連付けた知見は新しく興味深いと思われ る (図 5 と表 2 )。このことは，潜在的心疾患リスクゃ 体液量過剩リスクの予知能の面で HBP が OBP を凌 駕する可能性を示唆している。近年, 早朝高血圧が脳・ 心・腎のさまざまなイベントと関連する成績が多い が 支持されることが示唆された。

病因論の観点から今回の検討は BNP と心肥大 · 心 不全あるいは ANP と体液量関連パラメーターなどと の関連を定量的に同定したものではない，朝方の交感 神経活性圥進注早朝血圧を惹起し，これが心肥大 · 心 不全のリスクとなり BNP 高值に帰結している可能性 が考元られる、今後, HBP を用いた高血圧臨床は広く 普及しさまざまなデー夕が集積することが期待され る. HD 患者に扔いても家庭に扔汸る HBP 測定を推 奨し BNPやANP と定量的に関連付けることによ
り，減塩指導強化による体液量過剩抑制，より適正な ドライウエイトの再評価，早朝高血圧を視野に入れた 降圧療法の工夫，などで览格な高血圧管理が可能とな り心血管合併症進展をより効率的に抑制し得ると思わ れる。

以上をまとめると，現行での HD 患者は血圧管理状 況が極めて不十分であり依然高リスク患者群であるこ と，これらの患者の潜在性的心血管疾患りスクや体液 過剩状態は家庭で得られた HBP の方が OBPより鋭 敏な予知因子である可能性があることが, 結論される。

本研究の内容の一部は第 51 回日本透析医学会総会 （2006 年 6 月，横浜）に扔いて発表した。

\section{文献}

1) Imai $Y$, Ohkubo T, Tsuji I, Hozawa A, Nagai K, Kato J, Kikuya M, Aihara A, Sekino M, Michimata M, Matsubara M, Ito S, Satoh H, Hisamichi S : Relationships among blood pressure obtained using different methods in general population of Ohasama, Japan. Hypertens Res $22: 262-272,1999$

2) Imai $Y$, Nishiyama $A$, Sekino $A$, Aihara $A$, Kikuya M, Ohkubo T, Matsubara M, Hozawa A, Tsuji I, Ito $\mathrm{S}$, Satoh H, Nagai K, Hisamichi S : Characteristics of blood pressure measured at home in the morning and in the evening : the Ohasama study. J Hypertens $17: 889-898,1999$

3) Ohkubo T, Obara $T$, Funahashi J, Kikuya $M$, Asayama K, Metoki H, Oikawa T, Takahashi H, Hashimoto J, Totsune K, Imai Y and the J-HOME Study Group: Control of blood pressure as measured at home and office, and comparison with physicians' assessment of control among treated hypertensive patients in Japan : First report of the Japan Home versus office blood pressure measurement evaluation (J-HOME) study. Hypertens Res 27: 755-763, 2004

4) Kario K, Pickering TG, Umeda $Y$, Hoshide S, Hoshide Y, Morinari M, Murata M, Kuroda T, Schwartz JE, Shimada K : Morning surge in blood pressure as a predictor of silent and clinical cerebrovascular disease in elderly hypertensives. A prospective study. Circulation 107 : 1401-1406, 2003

5) Muller JE, Stone PH, Turi ZG, Rutherford JD, Czeisler CA, Parker C, Poole WK, Passamani E, Roberts R, Robertson $\mathrm{T}$ : Circadian variation in the frequency of onset of myocardial infarction. N Engl J Med 313 : 1315-1322, 1985

6) Elliot WJ : Circadian variation in the timing of stroke onset : a meta-analysis. Stroke 29:992-996, 1998 
7) Marler JR, Price TR, Clark GL, Muller JE, Robertson T, Mohr JP, Hier DB, Wolf PA, Caplan LR, Foulkes MA: Morning increase in onset of ischemic stroke. Stroke 20:473-476, 1989

8) Ikeda T, Gomi $T$, Shibuya $Y$, Matsuo K, Kosugi $T$, Oku N, Uetake Y, Kinugasa S, Furutera R : Morning rise in blood pressure is a predictor of left ventricular hypertrophy in treated hypertensive patients. Hypertens Res 27 : 939-946, 2004

9) Suzuki H, Nakamoto H, Okada H, Sugahara S, Kanno Y : Self-measured systolic blood pressure in the morning is a strong indicator of decline of renal function in hypertensive patients with no-diabetic chronic renal insufficiency. Clin Exp Hypertens 24 : 249-260, 2002

10) Kario K, Pickering TG, Hoshide S, Eguchi K, Ishikawa K, Morinari M, Hoshide Y, Shimada K : Morning blood pressure surge and hypertensive cerebrovascular disease. Role of the alpha adrenergic sympathetic system. Am J Hypertens 17 : 668-675, 2004

11) Aihara $A$, Imai $Y$, Sekino $M$, Kato J, Ito $S$, Ohkubo T, Tsuji I, Satoh H, Hisamichi S, Nagai K : Discrepancy between screening blood pressure and ambulatory blood pressure : a community based study in Ohasama. Hypertens Res $21: 127-136,1998$

12) Ohkubo T, Imai $Y$, Tsuji I, Nagai K, Kato J, Kikuchi N, Nishiyama A, Aihara A, Sekino M, Kikuya S, Ito $\mathrm{S}$, Satoh H, Hisamichi S : Home blood pressure measurement has a stronger predictive power for mortality than does screening blood pressure measurement: a population based observation in Ohasama. J Hypertens 16 : 971-975, 1998

13) Bakris GL, Williams M, Dworkin K, Elliotte WJ, Epstein M, Toto R, Tuttle K, Douglas J, Hsueh W, Sowers $\mathrm{J}$ : Preserving renal function in adults with hypertension and diabetes: a consensus approach. National Kidney Foundation Hypertension and Diabetes Executive Committees Working Group. Am J Kidney Dis 36 : 646-661, 2000

14) Kamoi K, Miyakoshi M, Soda S, Kaneko S, Nakagawa $\mathrm{O}$ : Usefulness of home blood pressure measurement in the morning in type 2 diabetic patients. Diabetes Care 25:2218-2223, 2002

15) Zanchetti A, Hansson L, Dahlof B, Elmfeldt D,
Kjeldsen S, Kolloch R, Larochelle P, McInnes GT, Mallion JM, Ruilope L, Wedel H : Effect of individual risk factors on the incidence of cardiovascular events in the treated hypertensive patients of the Hypertension Optimal Treatment Study. HOT Study Group. J Hypertens 19: 1149-1159, 2001

16) Klag MJ, Whelton PJ, Randall BL, Neaton JD, Brancati FL, Ford CE, Schulman NB, Stamler J : Blood pressure and end-stage renal disease. N Engl J Med 334 : 13-18, 1996

17) Santos SF, Mendes RB, Santos CA, Dorigo D, Peixoto $\mathrm{AJ}$ : Rrofile of interdialytic blood pressure in hemodialysis patients. Am J Nephrol 23:96-105, 2003

18) Horl MP, Horl WH:Hemodialysis-associated hypertension : pathophysiology and therapy. Am J Kidney Dis $39: 227-244,2002$

19）家庭血圧測定条件設定の指針, 日本高血圧学会, 2003, ライフサイエンス社

20) Joffy S, Rosner MH : Natriuretic peptides in ESRD. Am J Kidney Dis $46: 1-10,2005$

21) Zoccali C, Tripepi G, Mallamaci F : Predictors of cardiovascular death in ESRD. Seminars in Nephrol 25:358-362, 2005

22) Goodkin DA, Young EW, Kurokawa K, Prutz KG, Levin NW : Mortality among hemodialysis patients in Europe, Japan, and the United States : case-mix effects. Am J Kidney Dis 44 (Suppl 2) : s16-s21, 2004

23) Kuriyama $S$, Otsuka $Y$, Iida $R$, Matsumoto $K$, Tokudome G, Hosoya T: Morning blood pressure predicts hypertensive organ damages in patients with renal diseases: Effect of intensive antihypertensive therapy in patients with diabetic nephropathy. Intern Med $44: 1239-1246,2005$

24）栗山 哲, 大塚泰史, 飯田里菜子, 小林政司，山岸弘 子, 細谷龍男：腹膜透析患者における早朝高血圧と降 圧療法。日腎誌 $47: 38-45,2005$

25) Kario $\mathrm{K}:$ Morning surge and variability in blood pressure. A new therapeutic target? Hypertension $45: 485-486,2005$

26）栗山 哲, 友成治夫, 㱜田美穗, 吉田裕明, 国枝试彦, 四家敏秀，川口良人，酒井 紀：慢性腎不全透析患者 の体液量の指標としての ANP, BNP, cyclic-GMP の 臨床的意義. 透析会誌 $29: 1143-1151,1996$ 